\title{
Reduction in the Emission Rate of Greenhouse Gases and the Increase in Crop Production by Using Compost on Marginal Land
}

\author{
Isrun $^{1 *}$, Uswah Hasanah ${ }^{1}$, Syamsuddin Laude $^{1}$, Muhammad Basir-Cyio $^{1}$, Fadhliah $^{2}$, Effendy $^{3}$ \\ ${ }^{1}$ Department of Agrotechnology, Faculty of Agriculture, Tadulako University, Palu 94118, Indonesia \\ ${ }^{2}$ Department of Communication Science, Faculty of Social and Political Science, Tadulako University, Palu 94118, Indonesia \\ ${ }^{3}$ Department of Agriculture Economics, Agriculture Faculty of Tadulako University, Palu 94118, Indonesia
}

Corresponding Author Email: isrun.isrun@yahoo.com

https://doi.org/10.18280/ijdne.160513

Received: 8 July 2021

Accepted: 3 September 2021

\section{Keywords:}

greenhouse gases, emission, agricultural production, straw rice compost, cocoa pod husk

\begin{abstract}
Greenhouse gases dominated by $\mathrm{CO}_{2}, \mathrm{CH}_{4}, \mathrm{CFC}$, and $\mathrm{N}_{2} \mathrm{O}$ come from human (anthropogenic) activities. Efforts to increase the production of rice and corn crops require organic and inorganic fertilizers. The use of chemical fertilizers, which can increase greenhouse gas emissions, is higher than that of organic fertilizers. This study aimed to investigate the reduction in the greenhouse gas emission rate and the increase in crop production caused by organic fertilizer from rice straw and cocoa peel, a community-based sustainable development approach based on education. This research used the mixed method, a descriptive and simple experimental design with the following treatments: $\mathrm{t} 0=$ without Compost; $\mathrm{ta}=$ straw rice compost dosage of $3 \mathrm{t} \mathrm{ha}^{-1} ; \mathrm{tb}=$ cocoa pod husk dosage of $3 \mathrm{t} \mathrm{ha}^{-1}$; Bta $=$ maize crops + without compost $(\mathrm{t} 0)$; $\mathrm{Btb}=$ maize crops + cocoa pod husk compost (tb); Sta $=$ bare soil + without compost $(\mathrm{t} 0) ; \mathrm{Stb}=$ rice crops + straw compost $(\mathrm{ta}) ; \mathrm{Stc}=$ rice crops + cocoa pod husk compost $(\mathrm{tb})$; and Std $=$ rice crops + without compost $(\mathrm{t} 0)$. The application of compost reduced agricultural waste and greenhouse gas emissions of $\mathrm{CH}_{4}$ and $\mathrm{N}_{2} \mathrm{O}$ in both maize and rice fields. Greenhouse gas emissions were reduced by 30 percent compared to those under the application of chemical fertilizers. The utilization of compost as organic fertilizer also increased the production of corn and rice crops compared to that without the application of agricultural waste up to 10.3 tons per ha.
\end{abstract}

\section{INTRODUCTION}

The role of the agricultural sector is to produce food for the entire population of a country, which is especially challenging for countries with a large population. Based on the results of the 2017 population census, Indonesia, which has 262 million people, requires the availability of sustainable food so that community needs can be fulfilled. Indonesia's growing population continues to increase, making it the fourth most populous country after China, India and the United States. Due to population growth, the amount of food demand is getting bigger and bigger [1]. The loss of food production capacity and the loss of soil fertility will become increasingly serious problems. To support food security, it is necessary to develop strategies in the field of food through the improvement of agricultural practices on paddy fields and corn crops on dry land with organic fertilizer from agricultural waste. This process is very beneficial since it improves the soil both physically and chemically. However, high utilization of agricultural waste with carbon and nitrogen contents can be a source of greenhouse gases, especially methane $\left(\mathrm{CH}_{4}\right)$ and nitrous oxide $\left(\mathrm{N}_{2} \mathrm{O}\right)$, which increases global warming $[2,3]$. Agriculture as a source of $\mathrm{CH}_{4}$ and $\mathrm{N}_{2} \mathrm{O}$ emissions is a topic that has been studied by many countries, mainly developed countries in Europe and the United States. $\mathrm{N}_{2} \mathrm{O}$ emissions from synthetic fertilizers and $\mathrm{CH}_{4}$ emissions from fermented materials stimulate carbon accumulation in soil [4].
Soil inundation under reductive conditions stimulates decomposition and methanogenic microorganisms to become more active so that $\mathrm{CH}_{4}$ gas synthesis in the rhizosphere also increases [5,6]. Agricultural waste such as straw and cocoa pod husk is the primary choice for rice and cocoa production in Central Sulawesi and addresses the limited availability of fertilizer in Indonesia. The average rice production in Indonesia 2010-2016 reached 432 thousand tons, mainly in Palu Valley, indicating the potential for the production of straw waste that can be utilized as organic fertilizer [7, 8]. Technically, the use of rice straw as an organic fertilizer has been considered unfavorable when it is immersed directly into rice fields, stimulating greenhouse gas emissions, mainly $\mathrm{CH}_{4}$, in stagnant conditions because of its high $\mathrm{C} / \mathrm{N}$ ratio [9].

The use of agricultural waste is part of the effort to utilize local resources in accordance with the principle of sustainable development, which is considered integral to social, economic, and environmental health [10]. These three strategic components have their own challenges, although they cannot be separated, with the social, economic and environmental systems involved in the provision of human needs [11].

Education is one of the crucial processes that is expected to build a framework for the success of sustainable development $[12,13]$. Since 2005, the United Nations (UN) has declared the "Decade of Education for Sustainable Development, 20052014", which has the purpose of empowering people to utilize existing resources, including agricultural wastes, that can be 
processed into organic fertilizer in the form of compost [14]. The amount of agricultural waste that can provide a source of organic fertilizer is very abundant; in Java, this waste has been applied as organic fertilizer, mainly in Northern Coast (Pantura) regions, although the handling process is not in accordance with expectations. For the Sulawesi region, agricultural waste material in the form of rice straw and cocoa pod husk has not been widely used.

Central Sulawesi cocoa bean production reached 149.5 thousand tons in 2014 , which can potentially produce cocoa pod husk waste. Similarly, large areas of rice crops produce many plant residues (straw); if the straw is not properly handled, it potentially becomes waste. Conversely, if it is handled properly as raw material for organic fertilizer through a variety of scientifically informed processes then it can be developed and used by the community itself, a process empowered through informal education.

In contrast to the description above, the study of agricultural waste utilization as a raw material for compost-based organic fertilizer is an effort to reduce the rate of methane and nitrous oxide emissions from paddy fields and dry lands and increase the quality of marginal land to support sustainable food security and environmentally friendliness, as one aspect of the Education for Sustainable Development mission.

\section{MATERIALS AND METHODS}

The data and information collection used integrated methods, namely, the descriptive method, simple experimental design, and survey method. To identify the nutrient content of each agricultural waste, laboratory tests were conducted at the Environmental Laboratory of the Faculty of Agriculture, Tadulako University. Human Ecosystem Analysis--HESA was used to determine the involvement of the farmer community [15] in the process of making compost from agricultural waste and how to use it.

The soil fertility and greenhouse gas emissions were measured from wet and dry lands using standardized testing methods that have been applied for both soil and gas analyses. Specifically, the analysis of $\mathrm{CH}_{4}$ and $\mathrm{N}_{2} \mathrm{O}$ greenhouse gas emissions was conducted in the Laboratory of Greenhouse Gases of Agriculture Research (Lolittan), Jekanan, Pati, Central Java in cooperation with the International Rice Research Institute (IRRI).

The study started from June to September 2019 and continued by field implementation monitoring in 2020 at three locations in Palu Valley of Central Sulawesi Province. To determine the nutrients, compost was analyzed in the Laboratory of the Environment, Faculty of Agriculture, Tadulako University, while the treatment of rice straw compost was conducted on marginal land with alkaline soil. Straw and cocoa pod husk compost treatments were conducted in the area of corn fields in the Sigi Biromaru subistrict, Sigi District.

The field data required for the purposes of interpretation (justification) were acquired through the prepared treatments as follows:

- $\quad \mathrm{t} 0=$ without compost;

- $\quad$ ta $=$ straw rice compost dosage of $3 \mathrm{t} \mathrm{ha}^{-1}$;

- $\quad \mathrm{tb}=$ cocoa pod husk dosage of $3 \mathrm{t} \mathrm{ha}^{-1}$;

- $\quad$ Bta = maize crops + without compost $(\mathrm{t} 0)$;
- $\quad$ Btb = maize crops + cocoa pod husk compost $(\mathrm{tb}) ;$

- $\quad$ Sta = bare soil + without compost (t0);

- $\quad \mathrm{Stb}=$ rice crops + straw compost (ta);

- $\quad$ Stc $=$ rice crops + cocoa pod husk compost $(\mathrm{tb})$;

- $\quad \mathrm{Std}=$ rice crops + without compost (t0).

$\mathrm{CH}_{4}$ and $\mathrm{N}_{2} \mathrm{O}$ gas emission data were collected in the form of time series to see the cross-treatment emission rate and not the cross-section. To determine the effect of rice straw and cocoa pod husk application on the nutrient release rate, $\mathrm{pH}$, KTK, N, P, K, Ca, S, Mg, and Na were measured.

Data collection was conducted one week after compost treatment or two weeks after transplanting (WAT). To collect the gas samples in the rice fields, a flux collecting box was used, which was coupled with a plastic syringe with a volume of $5 \mathrm{ml} . \mathrm{CH}_{4}$ and $\mathrm{N}_{2} \mathrm{O}$ emission rates were calculated by using the mathematical approach proposed by Rolston [16-18] as follows:

$$
F=\left(\frac{V}{A}\right)\left(\frac{\Delta C}{\Delta t}\right)
$$

where,

$$
\begin{aligned}
\mathrm{F} & =\mathrm{CH}_{4} \text { and } \mathrm{N}_{2} \mathrm{O} \text { gas emission rates }\left(\mathrm{mg} \mathrm{m}^{-2} \mathrm{~h}^{-1}\right), \\
\mathrm{V} & =\text { emission box container volume }\left(\mathrm{m}^{3}\right), \\
\mathrm{A} & =\text { large box }\left(\mathrm{m}^{2}\right), \\
\Delta \mathrm{C} & =\text { concentration difference of } \mathrm{t}_{1}-\mathrm{t}_{\mathrm{o}}\left(\mathrm{mg} \mathrm{m}^{-3} / \mathrm{ppm}\right), \\
\Delta \mathrm{t} & =\text { gas collecting period }(\mathrm{h}) .
\end{aligned}
$$

The analyzed soil characteristics in the test location included soil acidity $(\mathrm{pH})$, exchangeable bases $(\mathrm{Ca}, \mathrm{Mg}, \mathrm{K}$ and $\mathrm{Na}$ ), cation exchange capacity $(C E C)$, base saturation $(B S)$, available $\mathrm{P}$, total $\mathrm{N}$, available $\mathrm{K}$, and organic $\mathrm{C}$ contents. The results of the soil analysis before the experiments for the dry land/mixed gardens indicated a $\mathrm{pH}\left(\mathrm{H}_{2} \mathrm{O}\right)$ of 6.4-6.8, and it was categorized as slightly acidic to neutral; for the rice field soil, it was categorized as slightly acidic to acidic (5.5-5.7). The contents of soil C-organic and $\mathrm{N}$-total in both the mixed garden and rice field were generally low, and $\mathrm{P}_{2} \mathrm{O}_{5}$ and $\mathrm{K}_{2} \mathrm{O}$ ranged from very low to low. Other soil characteristics examined were the cation exchange capacity $(C E C)$, base saturation $(B S)$ and exchangeable bases, which are presented in Table 1.

\section{RESULTS AND DISCUSSION}

\subsection{Nutrient contents of cocoa pods and rice straw}

The results of the nutrient content analysis of the organic fertilizers made from cocoa pod husk and rice straw are presented in Table 2.

The data in Table 2 show that the nitrogen content $(\mathrm{N})$ in rice straw and cocoa pod husk compost exceeded the critical values of the compost, so it was easily mineralized. According to Khan [19], mineralization in compost occurs when the $\mathrm{N}$ content is above the $\mathrm{N}$-critical value, which is between $1.5 \%$ and $2.5 \%$. Enzai and Ata $[20,21]$ emphasized that the critical value of nitrogen $(\mathrm{N})$ of compost ranges from $1.9 \%$ to $1.1 \%$; when the value is below that critical point, immobilization may occur. 
Table 1. Soil characteristic analysis of dry land/mixed garden $(K C)$ and rice field $(S W)$ sites

\begin{tabular}{|c|c|c|c|c|c|c|c|c|}
\hline \multirow{2}{*}{$\begin{array}{l}\text { Sample } \\
\text { Code }\end{array}$} & \multicolumn{2}{|c|}{$\mathrm{pH}(1: 2.5)$} & \multirow{2}{*}{$\begin{array}{c}\text { C Organic } \\
(\%)\end{array}$} & \multirow{2}{*}{$\begin{array}{c}\text { C Total } \\
(\%)\end{array}$} & \multirow{2}{*}{$\begin{array}{c}\text { N Total } \\
(\%)\end{array}$} & \multirow{2}{*}{$\mathrm{C} / \mathrm{N}$} & \multirow{2}{*}{$\begin{array}{c}\mathrm{HCl} 25 \% \mathrm{mg} / 100 \mathrm{~g} \\
(\mathrm{HCl} 25 \%)\end{array}$} & \multirow{2}{*}{$\begin{array}{c}\mathrm{K}_{2} \mathrm{O} 25 \% \mathrm{mg} / 100 \mathrm{~g} \\
(\mathrm{HCl} 25 \%)\end{array}$} \\
\hline & $\mathrm{H}_{2} \mathrm{O}$ & $\mathrm{KCl}$ & & & & & & \\
\hline $\mathrm{KC} 1$ & 6.6 & 5.5 & 1.13 & 1.5 & 0.11 & 13.64 & 14.39 & 57.44 \\
\hline $\mathrm{KC} 2$ & 6.4 & 5.3 & 1.25 & 1.66 & 0.13 & 12.92 & 26.98 & 16.56 \\
\hline $\mathrm{KC} 3$ & 6.6 & 5.7 & 1.01 & 1.35 & 0.15 & 6.96 & 16.43 & 12.76 \\
\hline SW1 & 5.5 & 4.4 & 2.74 & 3.65 & 0.29 & 12.58 & 14.44 & 49.79 \\
\hline SW2 & 5.5 & 4.3 & 1.54 & 2.05 & 0.17 & 12.08 & 20.46 & 10.54 \\
\hline SW3 & 5.7 & 4.6 & 2.2 & 3.05 & 0.27 & 12.7 & 20.73 & 11.27 \\
\hline \multirow{2}{*}{$\begin{array}{l}\text { Sample } \\
\text { Code }\end{array}$} & \multirow{2}{*}{$\begin{array}{c}\mathrm{P}_{2} \mathrm{O}_{5} \mathrm{ppm} \\
\left(\mathrm{Bray}^{-1}\right)\end{array}$} & \multicolumn{4}{|c|}{ Exchangeble Bases (me/100g Soil) } & CEC & \multirow{2}{*}{ BS me\% } & \multirow{2}{*}{ Al-Ex me\% } \\
\hline & & $\mathrm{Ca}$ & $\mathrm{Mg}$ & $\mathrm{K}$ & $\mathrm{Na}$ & me\% & & \\
\hline $\mathrm{KC1}$ & 8.13 & 3.39 & 0.88 & 1.01 & 0.2 & 7.5 & 73.07 & 0.37 \\
\hline $\mathrm{KC} 2$ & 16.98 & 5.1 & 1.09 & 0.54 & 0.27 & 8.4 & $\begin{array}{l}83.33 \\
145.4\end{array}$ & 0.32 \\
\hline $\mathrm{KC} 3$ & 14.67 & 7.91 & 1.32 & 0.32 & 0.24 & 6.73 & $\begin{array}{c}0 \\
127.6\end{array}$ & 0.26 \\
\hline SW1 & 8.16 & 18.3 & 3.85 & 0.87 & 0.21 & 18.24 & $\begin{array}{c}1 \\
118.6\end{array}$ & 0.5 \\
\hline SW2 & 16.22 & 9.01 & 2.11 & 0.87 & 0.19 & 10.27 & 4 & 0.52 \\
\hline SW3 & 13.97 & 11.3 & 2.18 & 0.2 & 0.21 & 15.25 & 91.16 & 0.51 \\
\hline
\end{tabular}

Table 2. Chemical composition of cocoa pod husk and rice straw composts

\begin{tabular}{ccccccc}
\hline \multirow{2}{*}{ Number } & \multirow{2}{*}{ Compost Type } & \multicolumn{5}{c}{ Content (\%) } \\
\cline { 3 - 7 } & & C-org & N-total & P & K & C/N Ratio \\
\hline 1. & Cocoa pod husk & 41.79 & 4.59 & 0.019 & 0.20 & 9.10 \\
2. & Rice straw & 43.08 & 4.60 & 0.021 & 0.20 & 9.37 \\
\hline \multicolumn{2}{l}{ Source: Laboratory of Soil Science, Faculty of Agriculture, Tadulako University, 2019}
\end{tabular}

Table 3. Average dry land content of C-organic, N-total, P and K-available in soil

\begin{tabular}{|c|c|c|c|}
\hline \multirow[b]{2}{*}{ Location } & \multicolumn{3}{|c|}{ Treatment } \\
\hline & Without Compost (T0) & Rice Straw (Ta) & Cocoa Pod Husk (Tb) \\
\hline \multirow{8}{*}{ Dry Land } & \multicolumn{3}{|c|}{ C-organic (\%) } \\
\hline & $1.81 \mathrm{a}$ & $2.17 \mathrm{~b}$ & $2.11 \mathrm{~b}$ \\
\hline & \multicolumn{3}{|c|}{$\mathrm{N}$-total (\%) } \\
\hline & $0.19 \mathrm{a}$ & $0.39 \mathrm{~b}$ & $0.32 \mathrm{~b}$ \\
\hline & \multicolumn{3}{|c|}{$\mathrm{P}$-available $\left(\mathrm{mg} \mathrm{kg}^{-1} \mathrm{P}_{2} \mathrm{O}_{5}\right)$} \\
\hline & $12.3 \mathrm{a}$ & $19.18 \mathrm{~b}$ & $18.53 \mathrm{~b}$ \\
\hline & \multicolumn{3}{|c|}{ K-available (me/100 g) } \\
\hline & $0.17 \mathrm{a}$ & $0.22 \mathrm{~b}$ & $0.20 \mathrm{~b}$ \\
\hline \multirow{8}{*}{ Rice Field } & \multicolumn{3}{|c|}{ C-organic (\%) } \\
\hline & $2.01 \mathrm{a}$ & $2.53 \mathrm{~b}$ & $2.44 \mathrm{~b}$ \\
\hline & \multicolumn{3}{|c|}{$\mathrm{N}$-total $(\%)$} \\
\hline & $0.20 \mathrm{a}$ & $0.36 \mathrm{~b}$ & $0.33 \mathrm{~b}$ \\
\hline & \multicolumn{3}{|c|}{$\mathrm{P}$-available $\left(\mathrm{mg} \mathrm{kg}^{-1} \mathrm{P}_{2} \mathrm{O}_{5}\right)$} \\
\hline & $14.7 \mathrm{a}$ & $19.32 \mathrm{~b}$ & $19.16 \mathrm{~b}$ \\
\hline & \multicolumn{3}{|c|}{ K-available (me/100 g) } \\
\hline & $0.19 \mathrm{a}$ & $0.26 \mathrm{~b}$ & $0.23 \mathrm{~b}$ \\
\hline
\end{tabular}

\subsection{Soil C-organic, N-total, $P$ and K-available}

The experimental results showed that the treatment with rice straw and cocoa pod husk compost could increase the Corganic, N-total, P and K-available in soil (Table 3).

Table 3 shows the treatment given was significantly different from the control. All observed response variables obtained the highest values under rice straw compost application for both rice and maize crops but were not significantly different from cocoa pod husk compost application. This is in accordance with the findings of Mahmoud et al. [22] which showed that the application of rice straw and animal wastes could increase the $\mathrm{C}$-organic, $\mathrm{N}$-total, $\mathrm{P}$ and $\mathrm{K}$-available in soil. The application of compost increased the soil C-organic, $\mathrm{N}$-total and $\mathrm{P}$ available contents.
C-organic increased from the low to moderate category, which was in the range of $1.81 \%$ to $2.17 \%$ on dry land and $2.01 \%$ to $2.53 \%$ on rice fields. The same also applied to $\mathrm{N}$-total and $\mathrm{K}$ available, but not $\mathrm{P}$-available, for which there was a marked increase in the control even though the overall level was low. Compost increased the $\mathrm{N}$-total in soil with the addition of organic compounds that can produce organic acids. When amino acids undergo hydrolysis, they produce ammonium $\left(\mathrm{NH}_{4}^{+}\right)$or nitrate $\left(\mathrm{NO}_{3}^{-}\right)$, making them available to crops. According to Huang [23], nitrogen-containing compounds produce ammonium, the first $\mathrm{N}$ - form derived from the decomposition of proteins through enzymatic processes assisted by heterotrophs. Ammonium is further converted into nitrate by microorganisms or plants. 


\section{3 $\mathrm{CH}_{4}$ greenhouse gas emissions}

The emission rate of methane $\left(\mathrm{CH}_{4}\right)$ tended to follow the growth pattern of plants; at the beginning of the growth, it tended to increase, and at 56-days-old, approximately 6 weeks after transplanting (MSTp), the rice crop showed the highest emissions, which then tended to decline after the primordial stage. The methane emissions under the rice straw and cocoa pod husk compost treatments were lower than those in soils without treatment, both in fields with crops and without crops, as illustrated in Figure 1.

The high cumulative emissions of $\mathrm{CH}_{4}$ in rice fields without compost is an indicator of a high carbon source, which stimulates methane emissions in rice fields without straw compost or cocoa pod husk compost. The low methane emissions in the composted field are the result of the low $\mathrm{C} / \mathrm{N}$ ratio of the organic matter undergoing mineralization processes. According to Jimenez and Xiong [24, 25], further mineralization of organic matter will minimize the formation and emissions of methane gas into the atmosphere. Bare soil had higher emission rates, similar to rice fields with crops but without compost. The higher emission trends under both conditions were due to the presence of remaining straw from the previous harvest season, which was partly decomposed, in addition to the habit of farmers to allow the straw to remain stacked without burning the straw or moving it to other places.

The average methane emissions during the rice cultivation period under the four soil conditions are presented in Table 4.

The average methane emissions during the rice cultivation period under the four soil conditions (Table 4) were highest in bare soil $\left(0.6723 \mathrm{mg} \mathrm{M}^{-2}\right.$ hour $\left.^{-1}\right)$ and the lowest was in flooded rice fields with crops and straw compost during plant growth, i.e., $0.1430 \mathrm{mg} \mathrm{M}^{-2}$ Hour $^{-1}$.

In rice fields, methane production and emissions are affected by the availability of substrates for methanogenic bacteria through litterfall production and root exudates that contain many carbohydrates and amino acids [26]. This position is supported by Khosa, Sidhu, and Benbi [27], who found that methane emissions from rice fields depend on anaerobic conditions, types of plants, and the application of organic matter.

The pattern of methane gas emissions between irrigated rice fields and dry land is basically the same; however, dry land

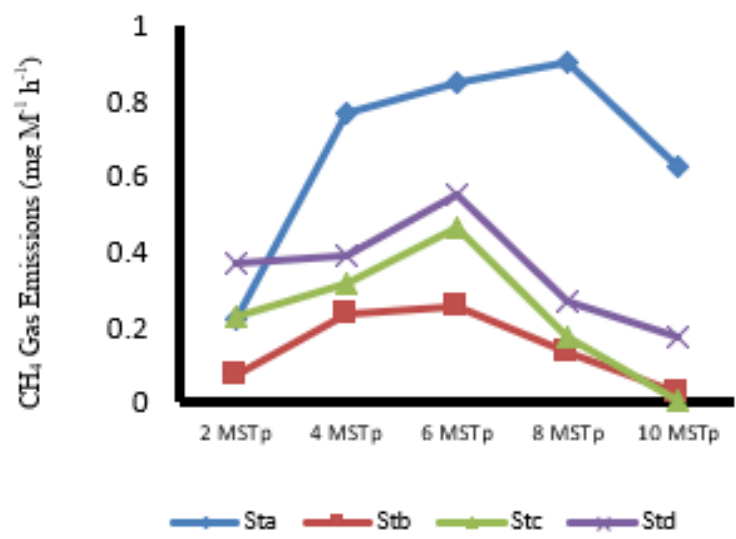

(A) with maize crops had a lower emission level, including total accumulation during the growth period of maize plants (Figure 2 ). The application of cocoa pod husk compost can reduce the rate and level of methane gas emissions more than those without cocoa pod husk compost.

Table 4 shows that the average rate of methane gas emissions in the composted corn field was only $-0.1283 \mathrm{mg} \mathrm{M}$ ${ }^{2}$ hour $^{-1}$. This negative emission of methane gas proves that the amount emitted from the rhizosphere to the atmosphere is far less than the amount of methane consumed by microorganisms. Research on the microbial consortia consuming methane is still limited, but Demirtepe [28] mentions that marine sediments under anaerobic conditions are believed to contain methane-consuming microbes as long as sulphate is available as the electron acceptor and methane is converted as an energy source.

In maize fields without cocoa pod husk compost, the emissions tended to be higher, that is, $0.034495 \mathrm{mg} \mathrm{M}^{-2}$ hour 1. This result indicates that even without the addition of organic matter to the maize field, the emissions remained higher than those in the composted maize fields. The release of organic compounds containing carboxyl groups via root exudation is suspected to stimulate methane gas emissions, so on dry land without cocoa pod husk compost, the emissions appeared higher than on lands with compost.

Root exudates potentially promote the formation and emission of methane gas into the atmosphere, which will increase when supported by methane-forming microorganisms. In addition, although the methane emission rates on dry land tend to increase as plants age, the rate of increase remains lower than that in irrigated rice fields. On dry land, soil temperatures are commonly higher than in wetlands (anaerobic soil), so the process of methane assimilation and the formation of methane gas is slower. The rate of oxidation and assimilation of methane in soil increases as soil temperatures increase from 5 to $20^{\circ} \mathrm{C}$ but decreases as temperatures increase from 20 to $30^{\circ} \mathrm{C}$ [29]. The soil temperature at the research location outside the mulch was approximately 35 to $37^{\circ} \mathrm{C}$, whereas that inside the mulch reached $41^{\circ} \mathrm{C}$ (Table 5).

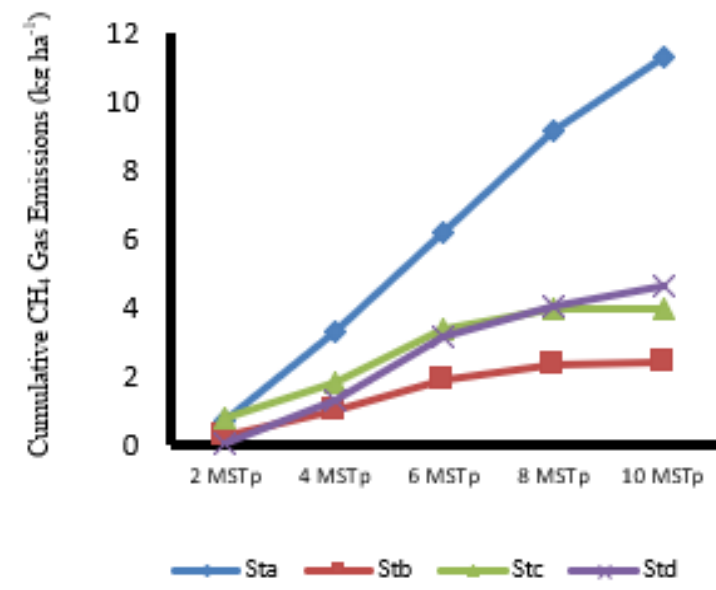

(B)

Figure 1. The emission rates (A) and accumulation (B) of methane gas in the irrigated rice field

Note: $\mathrm{STa}=$ bare soil + without compost $(\mathrm{T} 0) ; \mathrm{STb}=$ rice crops + straw compost $(\mathrm{Ta}) ; \mathrm{STc}=$ rice crops + cocoa pod husk compost $(\mathrm{Tb}) ; \mathrm{STd}=$ rice crops + without compost (T0); MSTp = weeks after transplanting 


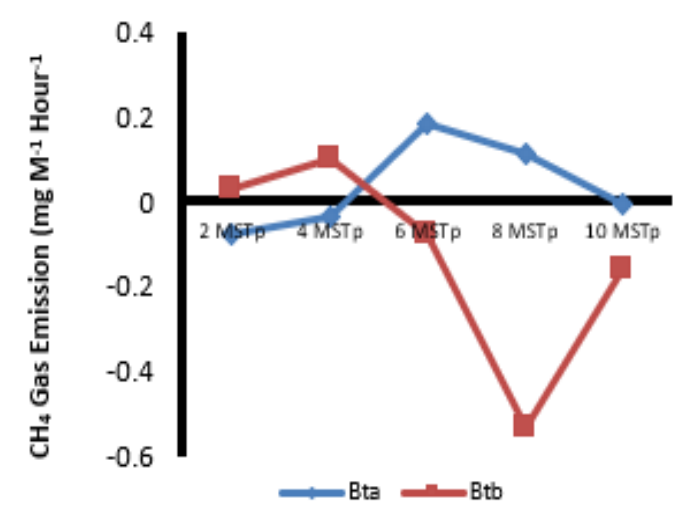

(A)

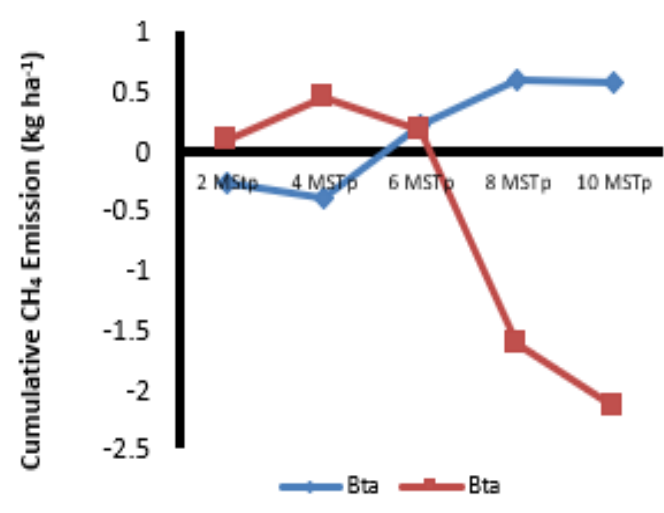

(B)

Figure 2. Emissions rates (A) and accumulation (B) of methane gas on dry maize crop land.

Note: $\mathrm{BTa}=$ Maize crops + without compost (T0); BTb = Maize crops + Cocoa Pod Husk Compost (Tb); MSTp = Week After Transplanting

Table 4. Methane emission rates ( $\left.\mathrm{mg} \mathrm{CH}_{4} \mathrm{M}^{-2} \mathrm{Hour}^{-1}\right)$ in irrigated rice fields with organic fertilizer application

\begin{tabular}{ccccccc}
\hline \multirow{2}{*}{ Treatment } & \multicolumn{5}{c}{ Week After Transplanting (MSTp) } \\
\cline { 2 - 6 } & $\mathbf{2}$ & $\mathbf{4}$ & $\mathbf{6}$ & $\mathbf{8}$ & $\mathbf{1 0}$ & Rata-rata \\
\hline BTa & -0.0799 & -0.0376 & 0.1816 & 0.1119 & -0.0034 & -0.0344 \\
BTb & 0.0285 & 0.1016 & -0.0788 & -0.5311 & -0.1283 \\
STa & 0.2193 & 0.7675 & 0.8463 & 0.9023 & 0.6259 & 0.6723 \\
STb & 0.0696 & 0.2307 & 0.2569 & 0.1324 & 0.0251 & 0.1430 \\
STc & 0.2284 & 0.3163 & 0.4637 & 0.1758 & 0.0057 & 0.2380 \\
STd & 0.3712 & 0.3906 & 0.5528 & 0.2661 & 0.1701 & 0.3502 \\
\hline
\end{tabular}

Note: $\mathrm{BTa}=$ maize crops + without compost $(\mathrm{T} 0) ; \mathrm{BTb}=$ maize crops + cocoa pod husk compost $(\mathrm{Tb}) ; \mathrm{STa}=$ bare soil + without compost $(\mathrm{T} 0) ; \mathrm{STb}=$ rice crops

+ straw compost $(\mathrm{Ta}) ; \mathrm{STc}=$ rice crops + cocoa pod husk compost $(\mathrm{Tb}) ; \mathrm{STd}=$ rice crops + without compost $(\mathrm{T} 0) ; \mathrm{MSTp}=$ weeks after transplanting

Table 5. Environmental temperature $\left({ }^{\circ} \mathrm{C}\right)$ of rice fields and dry lands

\begin{tabular}{ccccc}
\hline \multirow{2}{*}{ Measurement Time } & \multicolumn{4}{c}{ Environmental Temperature $\left({ }^{\circ} \mathrm{C}\right)$} \\
\cline { 2 - 5 } & \multicolumn{3}{c}{ Rice Field } & \multicolumn{3}{c}{ Dry Field } \\
\cline { 2 - 5 } & Outside Mulch & Inside Mulch & Outside Mulch & Inside Mulch \\
\hline $2 \mathrm{MSTp} / \mathrm{T}$ & 34 & 38 & 33 & 39 \\
$4 \mathrm{MSTp} / \mathrm{T}$ & 33 & 39 & 34 & 40 \\
$6 \mathrm{MSTp} / \mathrm{T}$ & 32 & 39 & 32 & 39 \\
$8 \mathrm{MSTp} / \mathrm{T}$ & 35 & 41 & 33 & 38 \\
$10 \mathrm{MSTp} / \mathrm{T}$ & 33 & 38 & 31 & 39 \\
\hline Average & 33.3 & 39.0 & 32.6 & 38.4 \\
\hline
\end{tabular}

A relatively high temperature will inhibit the methane genesis process since methanogenic microbes require an optimal temperature between 5 and $20^{\circ} \mathrm{C}$.

\section{4 $\mathrm{N}_{2} \mathrm{O}$ greenhouse gas emissions}

The highest nitrous oxide $\left(\mathrm{N}_{2} \mathrm{O}\right)$ GHG emissions in rice fields occurred when the rice crops were at the 6th MSTp in all treatments and subsequently decreased from that point until harvest time. The emission pattern of $\mathrm{N}_{2} \mathrm{O}$ appears to follow the growth of rice crops in line with the growth of the active tillering phase to the maximum tillering phase and peaks at the time of primordial flower development (Figure 3). The application of rice straw and cocoa pod husk compost decreased the $\mathrm{N}_{2} \mathrm{O}$ emission rate compared to other treatments.

The pattern of $\mathrm{N}_{2} \mathrm{O}$ emissions in maize fields also followed the growth of maize crops, and at the 8th and 10th MSTp, emissions tended to decrease again (Figure 4A), while the cumulative emissions during the growth period until harvest appeared lower in cocoa pod husk-composted areas (Figure 4B).

The application of rice straw and cocoa pod husk compost to both rice and maize fields (Figure 5) shows that both treatments can reduce the level of $\mathrm{N}_{2} \mathrm{O}$ emissions. In the maize field, $\mathrm{N}_{2} \mathrm{O}$ emissions decreased to $71.42 \%$ compared to those in the field without compost, and $\mathrm{N}_{2} \mathrm{O}$ emissions were significantly different based on the actual levels with LSD tests, $\alpha=0.05$. Similarly, the application of rice straw and cocoa pod husk compost in paddy fields suppressed $\mathrm{N}_{2} \mathrm{O}$ emissions by $30.39 \%$ to $42.62 \%$ compared to that in land with rice crops without compost (Std), and the difference was statistically significant based on the actual LSD test level of $\alpha=0.05$.

The high $\mathrm{N}_{2} \mathrm{O}$ emissions in the primordial flower growth stage or 6 MSTp that will decline during the productive stage mark the beginning of generative or reproductive growth in rice crops, during which root exudation is especially pronounced. This is the result of translocation of photosynthates from the leaves as a sink to the roots as a sink. [30] Root exudates serve as a source of energy for microorganisms, especially denitrifying bacteria in anaerobic soil conditions during metabolic processes [29]. Root exudates are rich in organic matter such as carbohydrates, organic acids, amino acids fermented into acetate or $\mathrm{CO}_{2}$ and $\mathrm{H}^{+}$, some of which are used as electron acceptors of certain microorganisms.

Rice fields potentially show increased $\mathrm{N}_{2} \mathrm{O}$ gas emissions when the amount of $\mathrm{N}$ is available for the microorganism 
transformation process, either from fertilizers, organic matter, or $\mathrm{N}$ in the soil, including $\mathrm{N}$ fixed from the air by the symbiosis of crops and $\mathrm{N}$-fixing microbes. Rice fields under anaerobic conditions are an ideal habitat for facultative anaerobic bacteria such as denitrifying bacteria that function well under adequate oxygen conditions or under $\mathrm{N}$-depleted conditions to emit $\mathrm{N}_{2} \mathrm{O}$ and fix $\mathrm{N}_{2}$. The application of rice straw to rice field soil tends to increase the rate of nitrogen fixation, denitrification and $\mathrm{N}_{2} \mathrm{O}$ emissions, but composting, including with both straw compost and cocoa pod husk compost, can reduce $\mathrm{N}_{2} \mathrm{O}$ gas emissions (Figure $5 \mathrm{~B}$ ).

The application of inorganic $\mathrm{N}$ fertilizer without rice straw compost and cocoa pod husk compost resulted in higher $\mathrm{N}_{2} \mathrm{O}$ emissions than compost application without inorganic

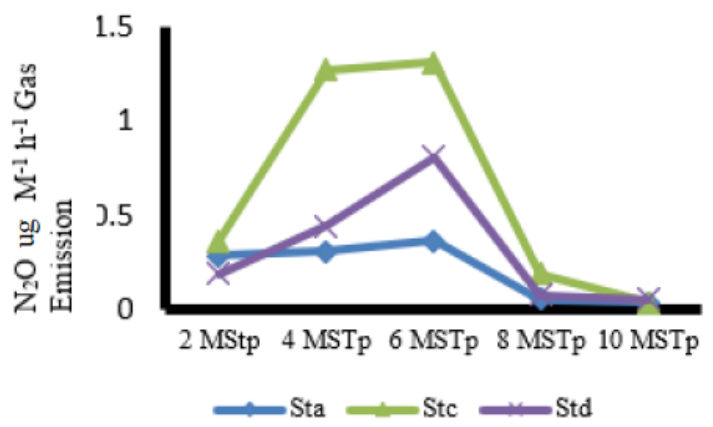

(A) fertilizer. The low $\mathrm{N}_{2} \mathrm{O}$ emissions in paddy fields treated with rice straw and cocoa pod husk compost were associated with declining populations of denitrifiers. In addition, compost fertilizer will inhibit the nitrification of $\mathrm{NH}_{4}{ }^{+}$to $\mathrm{NO}_{2}{ }^{-1}$ so that $\mathrm{N}_{2} \mathrm{O}$ [31] does not form. In addition, flooded soil conditions during the growth of plants create anaerobic soil conditions with a low Eh value that can reduce the content of $\mathrm{NO}_{3}{ }^{-1}$ and increase $\mathrm{NH}_{4}{ }^{+}$and its content, including the content of polyphenols in the soil [6]. The increase in the polyphenol content in the soil may inhibit the activity of nitrifying bacteria and denitrifying bacteria despite the availability of $\mathrm{NO}_{3}{ }^{-1}$, even when the population of denitrifying bacteria around the roots of rice crops is relatively high.

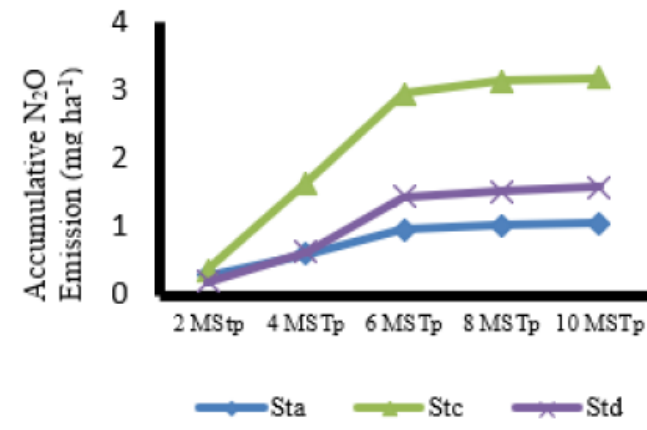

(B)

Figure 3. Emission rates $(\mathrm{A})$ and accumulation $(\mathrm{B})$ of dinitrous oxide gas in irrigated rice fields Note: Note: $\mathrm{STa}=$ bare soil + without compost $(\mathrm{T} 0) ; \mathrm{STb}=$ rice crops + straw compost $(\mathrm{Ta}) ; \mathrm{STc}=$ rice crops + cocoa pod husk compost $(\mathrm{Tb}) ; \mathrm{STd}=$ rice crops + without compost (T0); MSTp $=$ weeks after transplanting

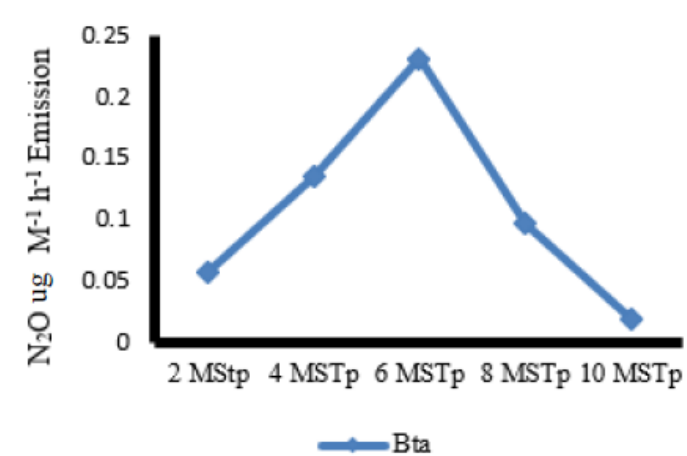

(A)

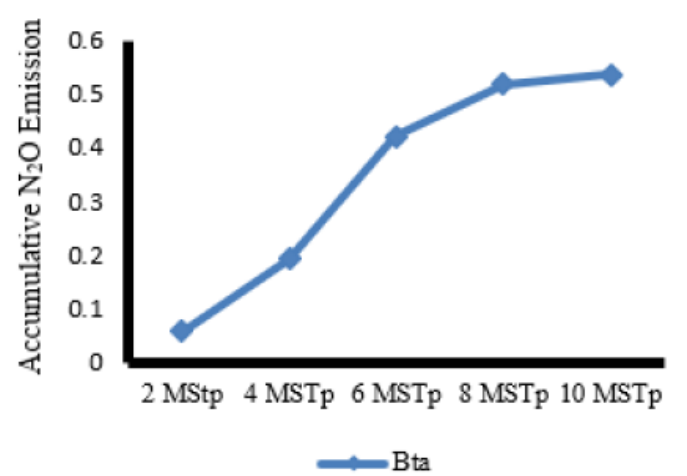

(B)

Figure 4. Emission rates (A) and accumulation (B) of nitrous oxide gas in the maize field Note: $\mathrm{BTa}=$ maize crops + without compost $(\mathrm{T} 0) ; \mathrm{BTb}=$ maize crops + cocoa pod husk compost $(\mathrm{Tb}) ; \mathrm{MST}=$ weeks after transplanting

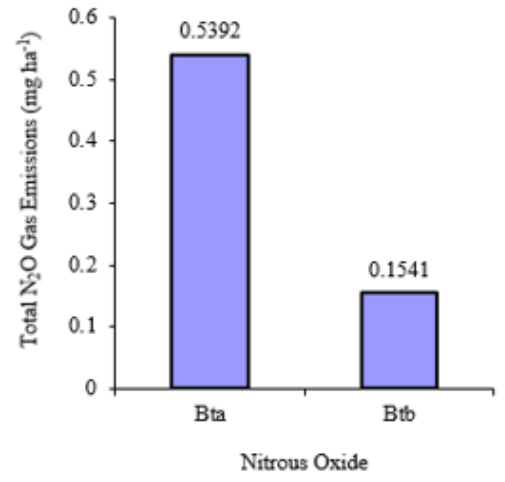

(A)

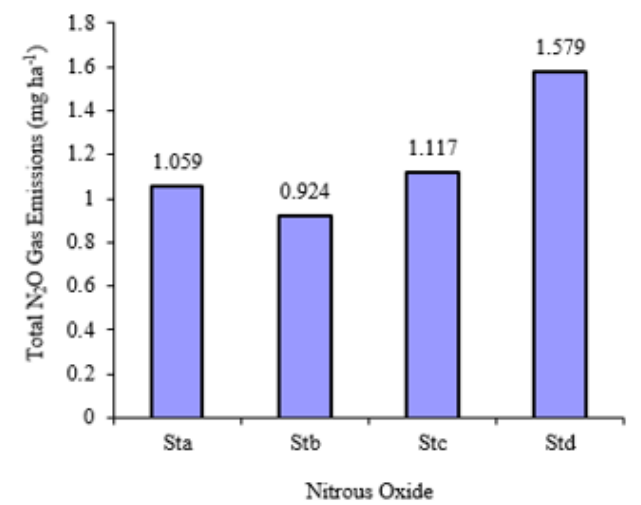

(B)

Figure 5. Total emissions of nitrous oxide in the maize field (A) and rice field (B)

Note: $\mathrm{Sta}=$ Rice field without crops without compost $(\mathrm{BS}) ; \mathrm{Stb}=$ Rice field with crops+straw compost $\left(\mathrm{T}_{1}\right)$; Stc $=$ rice field with crops + cocoa pod husk compost $\left(\mathrm{T}_{2}\right) ;$ and $\mathrm{Std}=$ rice field with crops without compost $\left(\mathrm{T}_{0}\right)$ 
Table 6. Average weight of sweet corn cobs without husks ( $\left.\mathrm{t} \mathrm{ha}^{-1}\right)$ with cocoa pod husk compost

\begin{tabular}{ccc}
\hline \multirow{2}{*}{ Explanation } & \multicolumn{2}{c}{ Treatment } \\
\cline { 2 - 3 } & Without Compost (T0) & Rice Straw Compost and Cocoa Pod Husk (Ta and Tb) \\
\hline Yield Productivity $\left(\mathrm{t} \mathrm{ha}^{-1}\right)$ & $6.3 \mathrm{a}$ & $13.3 \mathrm{~b}$ \\
Difference with the control & 0 & 3.0 \\
$\%$ Efficiency compared to the control & - & $48.6 \%$ \\
\hline
\end{tabular}

Note: Lowercase letters in the same line represent similarities with HSD test, $\alpha=0,05$

Table 7. Average yield of dried rice husk $\left(\mathrm{t} \mathrm{ha}^{-1}\right)$ with compost treatment

\begin{tabular}{cccc}
\hline \multirow{2}{*}{ Explanation } & \multicolumn{3}{c}{ Treatment } \\
\cline { 2 - 4 } & Without Compost (T0) & Rice straw (Ta) & Cocoa Pod Husk (Tb) \\
\hline Yield Productivity $\left(\mathrm{t} \mathrm{ha}^{-1}\right)$ & $6.2 \mathrm{a}$ & $9.2 \mathrm{~b}$ & $8.8 \mathrm{~b}$ \\
Difference to control & 0 & 3.0 & 2.6 \\
$\%$ Efficiency to control & - & $32.6 \%$ & $29.5 \%$ \\
\hline
\end{tabular}

Note: Lowercase letters in the same line represent similarities with HSD test, $\alpha=0.05$

\subsection{Maize yield}

Sweet corn cultivated in Entisols Palu Valley is very responsive to organic fertilizer, as measured by the result of cob weights without husks. The response of sweet corn to cocoa pod husk compost application is presented in Table 6.

Table 6 shows the highest yield of sweet corn achieved in the administration of 5 tons $\mathrm{ha}^{-1}$ of cocoa pod husk compost of $400 \mathrm{~g} \mathrm{plant}^{-1}$ or equivalent to $13.3 \mathrm{t} \mathrm{ha}^{-1 .}$ The highest yield achieved in Table 6 that exceeds the average yield of sweet corn farmers is 4.0-5.5 $\mathrm{t} \mathrm{ha}^{-1}$ and has reached the average yield standard range based on the description of sweet corn, which is $10 \mathrm{tha}^{-1}$.

The efficiency of yield increases with the application of organic fertilizer cocoa pod husk compost. The highest yield efficiency was $48.6 \%$, which was achieved from a dose of $5 \mathrm{t}$ $\mathrm{ha}^{-1}$ cocoa pod husk compost. In line with the results of research [32], the application of cocoa pod husk compost can increase the yield of sweet corn crops by $45.20 \%$.

The increase in yield as an effect of compost application reflects fairly good growth. This is because compost is an organic fertilizer that contains relatively complete nutrients that can provide essential elements for plants. Furthermore, [33] pointed out that organic matter can increase soil fertility and add nutrients and humus. It also affects the life of microorganisms that live in the soil, in addition to increasing the ability of the soil to reserve water. In soils with high organic content, nutrients become more available so that fertilization is more efficient.

The results of the economic analysis on the production of early harvested sweet corn are presented by taking into account the total cost of both fixed cost and variable cost. The value of $\mathrm{B} / \mathrm{C}$ ratio obtained was 1.9 .

\subsection{Yield of rice field}

The results show that organic fertilizer in rice fields has a positive effect on increasing rice production. The results obtained show that the productivity of rice fields increased up to $10.3 \mathrm{t} \mathrm{ha}^{-1}$ DUP (dry unhusked paddy) compared to that without organic fertilizer (control) with the production of 6.22 $\mathrm{t} \mathrm{ha}^{-1}$ DUP. The highest production was obtained from the use of rice straw compost at $10.3 \mathrm{tha}^{-1} \mathrm{DUP}$, followed by the use of cocoa pod husk compost at $9.6 \mathrm{t} \mathrm{ha}^{-1}$, as shown in the Table 7.

The highest yield was obtained from the rice straw compost treatment, with an efficiency of $32.6 \%$, while that of the cocoa fruit compost treatment was $29.5 \%$. This means that compost fertilizer acts as a source of nutrients to increase the availability of nutrients for plants so that the yield increases. The application of organic material in the form of chicken manure fertilizer to rice fields can increase yield by $15 \%$ [33].

\section{CONCLUSION}

It was obtained that the average $\mathrm{CH}_{4}$ emissions during the rice growing period for the four land conditions showed that the highest was in rice field without crop (unplanted soil), was $0.6723 \mathrm{mg} \mathrm{m}^{-2} \mathrm{~h}^{-1}$ followed by rice fields with rice crops but without additional compost, was $0.3502 \mathrm{mg} \mathrm{m}^{-2} \mathrm{~h}^{-1}$, rice cultivation paddy with cocoa compost in puddle condition during plant growth, that was $0.2380 \mathrm{mg} \mathrm{m}^{-2} \mathrm{~h}^{-1}$ while the lowest in rice field with rice straw compost which was applied in a stagnant condition during plant growth, i.e., $0.143 \mathrm{mg} \mathrm{m}^{-2}$ $\mathrm{h}^{-1}$. The highest average yield of sweet corn was $5.5 \mathrm{t} \mathrm{ha}^{-1}$, and the yield of rice fields was $10.3 \mathrm{tha}^{-1}$ compared to that without organic fertilizer (control), with a production of $6.22 \mathrm{t} \mathrm{ha}^{-1}$, followed by fruit skin compost treatment cocoa at $9.6 \mathrm{t} \mathrm{ha}^{-1}$.

\section{ACKNOWLEDGMENTS}

We would like to thank the Tadulako University for providing funding for this study.

\section{REFERENCES}

[1] Fancello, G., Paddeu, D., Fadda, P. (2017). Investigating last food mile deliveries: A case study approach to identify needs of food delivery demand. Res Transp Econ., 65: 56-66. https://doi.org/10.1016/j.retrec.2017.09.004

[2] Gardner, N., Manley, B.J.W., Pearson, J.M. (1993). Gas emissions from landfills and their contributions to global warming. Appl Energy, 44(2): 165-174. http://dx.doi.org/10.1016/0306-2619(93)90059-X

[3] Yu, X.Y., Barnett, J.M., Amidan, B.G., Recknagle, K.P., Flaherty, J.E., Antonio, E.J., Glissmeyer, J.A. (2018). Evaluation of nitrous oxide as a substitute for sulfur hexafluoride to reduce global warming impacts of ANSI/HPS N13.1 gaseous uniformity testing. Atmos Environ, 176: 40-46. 
http://dx.doi.org/10.1016/j.atmosenv.2017.12.015

[4] Shao, H., Yang, S., Cai, F., Li, C., Liang, J., Li, Q., Hyun, S., Kao, S.J., Dou, Y., Hu, B., Dong, G., Wang, F. (2016). Sources and burial of organic carbon in the middle Okinawa Trough during late Quaternary paleoenvironmental change. Deep Sea Res Part Oceanogr Res Pap, 118: 46-56. http://dx.doi.org/10.1016/j.dsr.2016.10.005

[5] Luo, J.Y., Zhang, S., Zhu, X..Z., Lu, L.M., Wang, C.Y., Li, C.H., Cui, J.J., Zhou, Z.G. (2017). Effects of soil salinity on rhizosphere soil microbes in transgenic $\mathrm{Bt}$ cotton fields. J Integr Agric, 16(7): 1624-1633 http://dx.doi.org/10.1016/S2095-3119(16)61456-9

[6] Zhu, J., Qu, B., Li, M. (2017). Phosphorus mobilization in the Yeyahu Wetland: Phosphatase enzyme activities and organic phosphorus fractions in the rhizosphere soils. Int Biodeterior Biodegrad, 124: 304-313. http://dx.doi.org/10.1016/j.ibiod.2017.05.010

[7] Basir-Cyio, M. (2003). Studi Perubahan Karakteristik Kimia Ultisol Palolo Akibat Lama dan Tinggi Genangan. Agroland J Ilmu-Ilmu Pertan, 10: 222-228.

[8] Basir-Cyio, M., Hasanah, U., Nur, I., Serikawa, Y. (2012). Gold mining activities and its impacts on land degradation in Central Sulawesi Indonesia. J Ecotechnology Res, 16(3-4): 79-83.

[9] Nurliyana, M.Y., H'ng, P.S., Rasmina, H., Kalsom, M.S.U., Chin, K.L., Lee, S.H., Lum, W.C., Khoo, G.D. (2015). Effect of $\mathrm{C} / \mathrm{N}$ ratio in methane productivity and biodegradability during facultative co-digestion of palm oil mill effluent and empty fruit bunch. Ind Crops Prod, 76 : $409-415$. http://dx.doi.org/10.1016/j.indcrop.2015.04.047

[10] Shen, W., Liu, Y., Yan, B., Wang, J., He, P., Zhou, C., Huo, X., Zhang, W., Xu, G., Ding, Q. (2017). Cement industry of China: Driving force, environment impact and sustainable development. Renew Sustain Energy Rev, 75:

$618-628$

http://dx.doi.org/10.1016/j.rser.2016.11.033

[11] Bokhorst, S., Berg, M.P., Wardle, D.A. (2017). Microarthropod community responses to ecosystem retrogression in boreal forest. Soil Biol Biochem, 110: 79-86. https://doi.org/10.1016/j.soilbio.2017.03.009

[12] Annan-Diab, F., Molinari, C. (2017). Interdisciplinarity: Practical approach to advancing education for sustainability and for the sustainable development goals Int J Manag Educ, 15(2): 73-83. http://dx.doi.org/10.1016/j.ijme.2017.03.006

[13] Faham, E., Rezvanfar, A., Movahed-Mohammadi, S.H., et al. (2017). Using system dynamics to develop education for sustainable development in higher education with the emphasis on the sustainability competencies of students. Technol Forecast Soc Change, 123: http://dx.doi.org/10.1016/j.techfore.2016.03.023

[14] Narodoslawsky, M. (2017). Bioenergy provision: utilizing contextual resources. Curr Opin Chem Eng, 17: 93-97. http://dx.doi.org/10.1016/j.coche.2017.07.002

[15] Fedele, G., Locatelli, B., Djoudi, H. (2017). Mechanisms mediating the contribution of ecosystem services to human well-being and resilience. Ecosyst Serv, 28: 4354. http://dx.doi.org/10.1016/j.ecoser.2017.09.011

[16] Rolston, D.E. (1986). Gas flux. In: Methods of Soil Analysis. ASA SSSA Madison Wis, 9: 1103-1119.

[17] Yang, S.S., Lai, C.M. (2002). Development and extension of the mitigationtechnology on greenhouse gases in agriculture sector, Taipei, Taiwan, Department of Agricultural Chemistry, National Taiwan University.

[18] IPCC. (2006). Guidelines for national greenhouse gas inventories, prepared by the national greenhouse gas inventories programme. IGES Jpn IPCC Natl Greenh Gas Invent Programme Tech Support Unit Inst Glob Environ Strateg, 2018: 240-0115.

[19] Khan, N., Clark, I., Sánchez-Monedero, M.A., Shea, S., Meier, S., Qi, F., Kookana, R.S., Bolan, N. (2016). Physical and chemical properties of biochars cocomposted with biowastes and incubated with a chicken litter compost. Chemosphere, 142: 14-23. http://dx.doi.org/10.1016/j.chemosphere.2015.05.065

[20] Du, E. (2017). Integrating species composition and leaf nitrogen content to indicate effects of nitrogen deposition. Environ Pollut, 221: 392-397. http://dx.doi.org/10.1016/j.envpol.2016.12.001

[21] Ata-Ul-Karim, S.T., Zhu, Y., Cao, Q., Rehmani, M.I.A., Cao, W., Tang, L. (2017). In-season assessment of grain protein and amylose content in rice using critical nitrogen dilution curve. Eur J Agron, 90: 139-151. http://dx.doi.org/10.1016/j.eja.2017.08.001

[22] Mahmoud, E., Ibrahim, M., Robin, P., Akkal-Corfini, N., El-Saka, M. (2009). Rice straw composting and its effect on soil properties. Compost Science \& Utilization, 17(3): 146-150. http://dx.doi.org/10.1080/1065657X.2009.10702415

[23] Huang, H., Huang, L., Zhang, Q., Jiang, Y., Ding, L. (2015). Chlorination decomposition of struvite and recycling of its product for the removal of ammoniumnitrogen from landfill leachate. Chemosphere, 136: 289296.

http://dx.doi.org/10.1016/j.chemosphere.2014.10.078

[24] Jimenez, J., Lei, H., Steyer, J.P., Houot, S., Patureau, D. (2017). Methane production and fertilizing value of organic waste: Organic matter characterization for a better prediction of valorization pathways. Bioresour Technol., 241: 1012-1021. http://dx.doi.org/10.1016/j.biortech.2017.05.176

[25] Xiong, J., Liu, X., Liang, L., Zeng, Q. (2017). Adsorption of methane in organic-rich shale nanopores: An experimental and molecular simulation study. Fuel, 200: 299-315. http://dx.doi.org/10.1016/j.fuel.2017.03.083

[26] Brye, K.R., Nalley, L.L., Tack, J.B., Dixon, B.L., Barkley, A.P., Rogers, C.W., Smartt, A.D., Norman, R.J., Jagadish, K.S.V. (2016). Factors affecting methane emissions from rice production in the Lower Mississippi river valley, USA. Geoderma Reg, 7: 223-229. http://dx.doi.org/10.1016/j.geodrs.2016.04.005

[27] Khosa, M.K., Sidhu, B.S., Benbi, D.K. (2010). Effect of organic materials and rice cultivars on methane emission from rice field. J Environt Biol., 31(3): 281-5.

[28] Demirtepe, H., Kjellerup, B., Sowers, K.R., Imamoglu, I. (2015). Evaluation of PCB dechlorination pathways in anaerobic sediment microcosms using an anaerobic dechlorination model. J Hazard Mater., 296: 120-127. http://dx.doi.org/10.1016/j.jhazmat.2015.04.033

[29] Faye, A., Sine, B., Chopart, J.L., Grondin, A., Lucas, M., Diedhiou, A.G., Gantet, P., Cournac, L., Min, D., Audebert, A., Kane, A., Laplaze, L. (2019). Development of a model estimating root length density from root impacts on a soil profile in pearl millet (Pennisetum glaucum (L.) R. Br). Application to measure 
root system response to water stress in field conditions. PLOS ONE, 14(7): e0214182. http://dx.doi.org/10.1371/journal.pone.0214182

[30] Banke-Thomas, A., Banke-Thomas, O., Kivuvani, M., Ameh, C.A. (2017). Maternal health services utilisation by Kenyan adolescent mothers: Analysis of the Demographic Health Survey 2014. Sex Reprod Healthc, 12: 37-46. http://dx.doi.org/10.1016/j.srhc.2017.02.004

[31] Girón-Rojas, C., Gil, E., Garcia-Ruiz, A., Iglesias, N., López, M. (2020). Assessment of biowaste composting process for industrial support tool development through macro data approach. Waste Manag., 105: 364-372. http://dx.doi.org/10.1016/j.wasman.2020.02.019

[32] Isrun, B. (2016). Study of Specific Fertilization Recommendation Locations in Sigi District., Center for Assessment of Natural Resources and Environment, Faculty of Agriculture, Tadulako University, Palu, Central Sulawesi. Unpub.

[33] Peigné, J., Vian, J.F., Payet, V., Saby, N.P.A. (2018). Soil fertility after 10 years of conservation tillage in organic farming. Soil Tillage Res., 175: 194-204. http://dx.doi.org/10.1016/j.still.2017.09.008 